\title{
The development of local interagency transition teams: A report from the Transition Alliance of South Carolina (TASC)
}

\author{
Jane M. Everson*, Joy Ivester and Leah Cordoni \\ Center for Disability Resources, University of South Carolina School of Medicine, Columbia, SC, USA
}

Revised/Accepted November 2018

\begin{abstract}
.
BACKGROUND: Locally-based and collaborative interagency transition teams have long been considered to be a "best practice" in the delivery of high school-to-adult life transition services for young adults with disabilities. Nevertheless, very little research exists assessing the specific team development and collaboration activities that these teams undertake in their efforts to improve outcomes for youth residing in their communities. As a result, although we believe local interagency teams are an effective vehicle for planning and delivering transition services, we know very little about the specific characteristics and activities of these teams. This is problematic for technical assistance (TA) providers, as well as for local team leaders, as we have limited guidance to offer teams in their initiation and membership struggles, goal setting and attainment activities, action planning models, or processes for reaching consensus. We have even less guidance to offer teams for their specific collaborative and interagency activities such as evaluating the viability of interagency agreements, the impact of joint personnel and service funding, or guidelines for making policy and procedural revisions.

OBJECTIVE: The purpose of this report is to explore these issues with local interagency teams in South Carolina by summarizing self-reported data on team development and collaboration interagency activities from 22 local interagency teams followed by the Transition Alliance of South Carolina (TASC) between September 2015 and September 2016. This report will also suggest TA activities for providers to focus upon as well as team leadership activities for local team leaders to use to initiate and lead teams in their local communities.
\end{abstract}

Keywords: Interagency collaboration, transition teams, team development

\section{Introduction}

Locally-based, collaborative interagency teams have been proposed as a fundamental component of high school-to-adult life transition models since the early 1980s. More recently, researchers have

\footnotetext{
*Address for correspondence: Jane M. Everson, Ph.D., University of South Carolina School of Medicine, Center for Disability Resources, 8301 Farrow Road, Columbia, SC 29203, USA. Tel.: +1828 238 5460; E-mail: jmeverson@ charter.net.
}

attempted to document a correlation between these teams and the enhancement of post-school outcomes for young adults with disabilities (e.g., Noonan, McCall, Zheng, \& Erickson, 2012; Povenmire-Kirk et al., 2015; Repetto, Webb, Garvan, \& Washington, 2002). As a result, there is an emerging body of research suggesting that the presence of interagency teams is correlated with employment, independent living, and other desired post-school outcomes for youth with disabilities. Nevertheless, very 
little research exists assessing the specific team development and collaboration activities that these teams undertake in their efforts to improve outcomes for youth residing in their communities.

TASC is a state-wide TA project funded primarily by the South Carolina Department of Education and supported by a collaboration of state agencies and organizations in South Carolina. The establishment and nurturing of local-level, collaborative interagency teams is one of its core components. As a result, TASC has supported the development of more than 50 teams throughout South Carolina. The purpose of this report is to summarize self-reported data on team development and collaboration activities from 22 teams followed by TASC between September 2015 and September 2016.

\section{Methodology}

To address activities associated with team development and collaborative interagency activities, TASC staff developed a three-part "Interagency Team Development and Collaboration Scale." The purpose of the scale is to obtain team-based, self-reported information about a team's development and operations. In addition to a brief demographic section, the scale includes two primary sections: part one presents 13 team development activities and part two presents 14 collaborative interagency activities. The 13 team development activities were suggested by the work of Everson and Guillory (2002) and the 14 collaborative interagency activities were suggested by the work of Dedrick and Greenbaum (2011). Following its initial development, the scale was reviewed by an expert panel of transition and evaluation experts from outside of South Carolina, and the scale was minimally revised. (For a copy of the scale, please contact the lead author.)

In September of 2015, TASC held a multiday conference addressing team development and collaborative interagency transition practices. Communities (i.e., school districts) were requested to send a group of school and adult service personnel and family representatives to the conference. Forty-one newly-forming teams attended, ranging in size from two people to more than eight people.

The conference agenda provided teams with presentations by state and local leaders on essential transition practices and provided time to work together as teams on strategic PATH planning ${ }^{1}$. At the beginning of the conference, the 41 participating groups were asked, as a team, to complete the scale by discussing each activity descriptor and reaching consensus as to whether each had been initiated, was in progress, or had been completed by the group. Following the workshop, 14 of the 41 groups applied for and were selected to receive structured team development TA from TASC staff. (Groups were not excluded from receipt of TA if they did not complete a scale nor were they given priority for receiving TA if they did complete a scale.) The remaining 27 groups did not receive structured team-based TA from TASC; however, group members may have participated throughout the year in general TASC-sponsored or other professional activities addressing transition services for young adults with disabilities.

TA was individualized to the needs identified by each newly-forming team, but included a variety of formats: on-site assistance provided by TASC staff and consultants during local interagency team meetings, telephone consultation before and after team meetings, invitations to participate in webinars provided by consultants, and invitations to attend follow-up workshops offered by consultants. TA content was also individualized and varied, but included, for example, assistance with defining team membership, identifying community needs, setting goals, addressing family and student engagement concerns, self-directed IEPs, and structuring and evaluating their activities and outcomes.

One year after attending the 2015 workshop, teams were asked to complete the scale again as a team, and again, by discussing and reaching consensus on each descriptor.

\section{Results}

Thirty-six of the 41 teams (an $88 \%$ response rate) completed the scale at the beginning of the workshop in September of 2015. All 14 of the teams selected after the conference to receive TA completed the scale (a $100 \%$ response rate) and 22 of the 27 teams that did

\footnotetext{
${ }^{1}$ Early in its development, TASC adopted and broadened the PATH model of person-centered planning to enable interagency teams to use the format and process to set long-term visions for their communities, identify pressing needs and available resources, enroll team members, set goals and activities, and evaluate their progress. For more information on the PATH process for interagency teams, please contact the lead author.
} 
not receive TA completed the scale (an $81 \%$ response rate).

One year after attending the workshop, in September of 2016, the 36 teams that completed the scale in 2015 were asked to complete the scale again. Twentytwo of the 36 teams completed the scale in 2016 (a $61 \%$ response rate.) Specifically, eight of the 14 teams selected to receive technical assistance completed the scale (a $57 \%$ response rate) and 12 of the remaining 27 teams completed the scale (a $44 \%$ response rate).

The remainder of this section of the report summarizes: 1) team development activities and 2) collaborative interagency team activities in 2015 and in 2016 for the 22 responding teams.

\subsection{Team development activities}

Team development is the process of bringing diverse groups of people together with goals, activities, and structures in order for members to address common needs and pursue common goals. Table 1 summarizes the extent of completion of the 13 team development descriptors reported by teams in 2015 and again in 2016.

Overall, responding teams came to the 2015 TASC conference feeling confident about their initial team development activities. Most had met as teams at least once before the conference. More than $3 / 4$ of the teams reported that they had completed or were progressing on initial team development activities. Specifically, teams were confident that they had completed or were making progress on identifying school and adult services personnel to serve on a core team, agreeing upon a community and a population to serve, agreeing upon a team meeting schedule, and were making progress on developing a PATH strategic plan. In the comments section of Part One, teams noted that they had completed or made progress on these team development activities in one or two team meetings.

A year later, in 2016, the responding teams had continued to make substantial progress on initial team activities as well as on more advanced team development activities: more than $90 \%$ had completed all initial team activities and were making progress with other more advanced team activities. Structural activities, such as use of action planning and role differentiation continued to be challenging, along with the use of PATH to make data-based decisions. Notably, in the comments section, those teams that had not completed these activities expressed difficulties with local personnel turn-over, both with school personnel assigned to manage transition activities and with administrative personnel authorized to promote teams. Several of these still developing teams expressed enthusiasm for the team-based model, but expressed uncertainty about their assigned role in leading the team, lack of time and skills, and lack of continuity of membership and paperwork (i.e., meeting minutes, action plans, PATH documents.) Overall, the only activity that teams did not selfreport substantial progress for between 2015 and 2016 were evaluation activities. Several teams, in the comments section, seemed to understand the importance of evaluation, including the use of data to guide their activities, as they requested TA in this area for upcoming years.

Teams that received TASC TA were slightly more likely to self-report completion of team development activities on the 2015 pre-scale and were also slightly more likely to self-report progress on the 2016 postscale than were teams that did not receive TA. Teams that received TA were also less likely to be hindered by team development concerns arising from personnel turnover, leadership uncertainty, and paperwork flow. There does not appear to be a difference between teams receiving or not receiving TA and their leadership on using PATH and other data for team-based evaluation activities.

\subsection{Interagency collaboration activities}

Interagency collaboration is the outcome of diverse groups of people working together across agency boundaries to address common needs and pursue common goals. In the arena of transition services, the focus of interagency collaboration activities would be the improvement of services and supports for the target population and community. Table 2 summarizes the extent of completion of the 14 collaborative interagency descriptors reported by teams in 2015 and again in 2016.

Overall, responding teams came to the 2015 TASC conference with an awareness of collaborative interagency activities that might be undertaken by their teams. Although teams did not indicate many completed activities, more than half of the teams reported making progress on activities such as sharing crossagency information and attending IEP/transition planning meetings. Teams were least likely to report collaboration on activities that required joint funding, such as shared office space, equipment, or personnel positions or on those that required potential policy and procedural revisions, such as common intake, referral and assessment forms or joint funding of 
Table 1

Team Development Activities

\begin{tabular}{|c|c|c|}
\hline Team Development Descriptor & $2015(\mathrm{~N}=36)$ & $2016(\mathrm{~N}=22)$ \\
\hline $\begin{array}{l}\text { 1. Leadership from school system and at } \\
\text { least one adult services agency } \\
\text { agreed to form a community } \\
\text { interagency team. }\end{array}$ & $\begin{array}{l}75 \% \text { had completed this task; } 22 \% \text { were } \\
\text { in progress; and } 3 \% \text { had not yet } \\
\text { initiated the task. }\end{array}$ & $\begin{array}{l}91 \% \text { had completed the task and } 9 \% \\
\text { were in progress. }\end{array}$ \\
\hline $\begin{array}{l}\text { 2. The team discussed and agreed upon a } \\
\text { specific community to serve. }\end{array}$ & $\begin{array}{l}83 \% \text { had completed the task; } 14 \% \text { were } \\
\text { in progress; and } 3 \% \text { had not yet } \\
\text { initiated the task. }\end{array}$ & $100 \%$ had completed the task. \\
\hline $\begin{array}{l}\text { 3. The team agreed upon a specific target } \\
\text { population to serve. }\end{array}$ & $\begin{array}{l}83 \% \text { had completed the task; } 14 \% \text { were } \\
\text { in progress; and } 3 \% \text { had not yet } \\
\text { initiated the task. }\end{array}$ & $100 \%$ had completed the task. \\
\hline $\begin{array}{l}\text { 4. The team identified all core members } \\
\text { to serve on the team. }\end{array}$ & $\begin{array}{l}75 \% \text { had completed the task; } 8 \% \text { were in } \\
\text { progress; and } 17 \% \text { had not yet } \\
\text { initiated the task. }\end{array}$ & $\begin{array}{l}86 \% \text { had completed the task; and } 14 \% \\
\text { were in progress. }\end{array}$ \\
\hline 5. The team developed a PATH. & $\begin{array}{l}69 \% \text { had completed the task; } 14 \% \text { were } \\
\text { in progress; and } 17 \% \text { had not yet } \\
\text { initiated the task. }\end{array}$ & $\begin{array}{l}91 \% \text { had completed the task; and } 9 \% \\
\text { were in progress. }\end{array}$ \\
\hline 6. The team confirmed team membership. & $\begin{array}{l}69 \% \text { had completed the task; } 17 \% \text { were } \\
\text { in progress; and } 14 \% \text { had not yet } \\
\text { initiated the task. }\end{array}$ & $\begin{array}{l}73 \% \text { had completed the task; and } 27 \% \\
\text { were in progress. }\end{array}$ \\
\hline $\begin{array}{l}\text { 7. The team developed a meeting } \\
\text { schedule. }\end{array}$ & $\begin{array}{l}69 \% \text { had completed the task; } 17 \% \text { were } \\
\text { in progress; and } 14 \% \text { had not yet } \\
\text { initiated the task. }\end{array}$ & $\begin{array}{l}91 \% \text { had completed the task; and } 9 \% \\
\text { were in progress. }\end{array}$ \\
\hline $\begin{array}{l}\text { 8. The team agreed upon "ground rules", } \\
\text { agenda development, action } \\
\text { planning, and procedures for } \\
\text { reaching consensus and voting. }\end{array}$ & $\begin{array}{l}30 \% \text { had completed the task; } 28 \% \text { were } \\
\text { in progress; and } 42 \% \text { had not yet } \\
\text { initiated the task. }\end{array}$ & $\begin{array}{l}68 \% \text { had completed the task; } 14 \% \text { were } \\
\text { in progress; and } 18 \% \text { had not yet } \\
\text { initiated the task. }\end{array}$ \\
\hline $\begin{array}{l}\text { 9. The team agreed upon procedures for } \\
\text { action planning. }\end{array}$ & $\begin{array}{l}28 \% \text { had completed the task; } 22 \% \text { were } \\
\text { in progress; and } 50 \% \text { had not yet } \\
\text { initiated the task. }\end{array}$ & $\begin{array}{l}68 \% \text { had completed the task; } 14 \% \text { were } \\
\text { in progress; and } 18 \% \text { had not yet } \\
\text { initiated the task. }\end{array}$ \\
\hline 10. The team agreed upon team roles. & $\begin{array}{l}39 \% \text { had completed the task; } 22 \% \text { were } \\
\text { in progress; and } 39 \% \text { had not yet } \\
\text { initiated the task. }\end{array}$ & $\begin{array}{l}77 \% \text { had completed the task; } 14 \% \text { were } \\
\text { in progress; and } 9 \% \text { had not yet } \\
\text { initiated the task. }\end{array}$ \\
\hline $\begin{array}{l}\text { 11. The team used its PATH is to set } \\
\text { team development goals. }\end{array}$ & $\begin{array}{l}6 \% \text { had completed the task; } 42 \% \text { were in } \\
\text { progress; and } 52 \% \text { had not yet } \\
\text { completed the task. }\end{array}$ & $\begin{array}{l}27 \% \text { had completed the task; } 67 \% \text { were } \\
\text { in progress; and } 4 \% \text { had not yet } \\
\text { initiated the task. }\end{array}$ \\
\hline $\begin{array}{l}\text { 12. The team used its PATH to set } \\
\text { student outcome goals. }\end{array}$ & $\begin{array}{l}6 \% \text { had completed the task; } 69 \% \text { were in } \\
\text { progress; and } 25 \% \text { had not yet } \\
\text { initiated the task. }\end{array}$ & $\begin{array}{l}6 \% \text { had completed the task; } 54 \% \text { were in } \\
\text { progress; and } 60 \% \text { had not yet } \\
\text { initiated the task. }\end{array}$ \\
\hline $\begin{array}{l}\text { 13. The team uses data to document } \\
\text { accomplishment of goals. }\end{array}$ & $\begin{array}{l}6 \% \text { had completed the task; } 19 \% \text { were in } \\
\text { progress; and } 75 \% \text { had not initiated } \\
\text { the task. }\end{array}$ & $\begin{array}{l}14 \% \text { had completed the task; } 86 \% \text { were } \\
\text { in progress; and } 0 \% \text { had not yet } \\
\text { initiated the task. }\end{array}$ \\
\hline
\end{tabular}

new transition services. In the comments section, the most likely collaborative activity to be described was hosting a "transition fair" for youth and their families.

A year later, in 2016, responding teams had made substantial progress with collaborative interagency activities. Overall, they indicated more sharing crossagency about roles, policies and procedures, and engaging in more cross-agency activities. Teams were most likely to report sharing during "transition fairs" and during attendance at IEP/transition planning meetings. Teams remained unlikely to have made substantial progress on activities requiring joint funding or expansion of services.

Teams that received TASC TA were slightly more likely to self-report completion and/or progress on collaborative interagency team activities than were teams that did not receive TASC TA.

\section{Discussion}

This report is intended to provide an exploratory evaluation of local interagency teams in South Carolina between September 2015 and September 2016. There are several limitations to the report. First, the scales provided self-report data, completed by local team members. Teams were asked to reflect on each activity, and as a team, reach consensus on the extent to which they had initiated or completed the activity. TASC staff did not request documentation of those 
Table 2

Interagency Collaboration Activities

Interagency Collaboration Activity

1. The team has written membership guidelines and roles.

2. Team members share information with each other about current policies and procedures.

3. Members share staff development information and transition-related activities with other members.

4. Members collaborate with training and outreach in transition-related activities.

5. Members share common intake forms and collected client information.

6. Members share common diagnostic, assessment, evaluation procedures and forms.

7. Members share common service delivery form plans and client information.

8. Members jointly attend IEP/transition planning meetings.

9. Members share office or other facility space.

10. Members share the funding of purchase of existing transition-related services.

11. Members jointly fund transition-related personnel positions.

12. Members have written interagency agreements or MOAs specifying existing areas of transition-related collaboration.

13. Members have written interagency agreements or MOAs specifying intent to plan and deliver new and/or expanded policies or procedures.

14. Members have written grant proposals specifying intent to collaborate on transition service delivery.
$2015(\mathrm{~N}=36)$

$6 \%$ had completed the task; $17 \%$ were in progress; and $77 \%$ had not initiated the task.

$19 \%$ had completed the task; $75 \%$ were in progress; and $6 \%$ had not yet initiated the task.

$8 \%$ had completed the activity; $50 \%$ were in progress; and $42 \%$ had not yet initiated the activity.

$17 \%$ had completed the activity; $50 \%$ were in progress; and $33 \%$ had not yet initiated the activity.

$3 \%$ had completed the activity; $14 \%$ were in progress; and $83 \%$ had not yet initiated the activity.

$3 \%$ had completed the activity; $14 \%$ were in progress; and $83 \%$ had not yet initiated the activity.

$8 \%$ had completed the activity; $6 \%$ were in progress; and $86 \%$ had not yet initiated the activity.

$8 \%$ had completed the activity; $42 \%$ were in progress; and $50 \%$ had not yet initiated the activity.

$8 \%$ had completed the activity; $42 \%$ were in progress; and $50 \%$ had not initiated the activity.

$0 \%$ had completed the activity; $48 \%$ were in progress; and $52 \%$ had not yet initiated the activity.

$0 \%$ had completed the activity; $48 \%$ were in progress; and $52 \%$ had not yet initiated the activity.

$8 \%$ had completed the activity; $42 \%$ were in progress; and 50\% had not yet initiated the activity.

$0 \%$ had completed the activity; $48 \%$ were in progress; and $52 \%$ had not initiated the activity.

$36 \%$ had completed the activity; $36 \%$ were in progress and $28 \%$ had not yet initiated the activity.
$2016(\mathrm{~N}=22)$

$23 \%$ had completed the task; $32 \%$ were in progress; and $45 \%$ had not yet initiated the task.

$32 \%$ had completed the task; $50 \%$ were in progress; and $18 \%$ had not yet initiated the task.

$23 \%$ had completed the activity; $45 \%$ were in progress; and $32 \%$ had not yet initiated the activity.

$77 \%$ had completed the activity; $14 \%$ were in progress; and $9 \%$ had not yet initiated the activity.

$4 \%$ had completed the activity; $23 \%$ were in progress; and $73 \%$ had not yet initiated the activity.

$4 \%$ had completed the activity; $23 \%$ were in progress; and $73 \%$ had not yet initiated the activity.

$9 \%$ had completed the activity; $23 \%$ were in progress; and $68 \%$ had not yet initiated the activity.

$36 \%$ had completed the activity; $50 \%$ were in progress; and $14 \%$ had not yet initiated the activity.

$9 \%$ had completed the activity; $23 \%$ were in progress; and $68 \%$ had not yet initiated the activity.

$0 \%$ had completed the activity; $64 \%$ were in progress; and $36 \%$ had not yet initiated the activity.

$4 \%$ had completed the activity; $32 \%$ were in progress; and $64 \%$ had not yet initiated the activity.

$14 \%$ had completed the activity; $82 \%$ were in progress; and $4 \%$ had not yet initiated the activity.

$0 \%$ had completed the activity; $100 \%$ had not yet initiated the activity.

$59 \%$ had completed the activity; $23 \%$ were in progress; and $18 \%$ had not yet initiated the activity. activities that teams indicated they had completed. Second, the teams were invited to attend a conference. Teams that chose to attend the conference and complete the scale may not reflect other non-participating teams in South Carolina. Third, teams that chose to respond to the scale in 2015 and 2016 may not reflect the perceptions of teams that chose not to complete the scale both years.

Nevertheless, the data from this evaluation activity do indicate some preliminary findings about local interagency teams as well as suggestions for future
TA and team leadership activities for local team leaders to use to initiate and lead teams in their local communities:

- Over a 12-month time period, local interagency teams did pursue and complete a number of team development and collaborative interagency activities that enhanced their ability to work as a team. The activities included articulating a PATH vision and goals, taking action toward attaining these goals, attaining a greater understanding of local 
needs and resources and developing a greater understanding of other agencies' services and their strength as teams.

- Over a 12-month time period, local interagency teams were also able to impact consumer transition services and outcomes by jointly planning "transition fairs" and other outreach activities, by increasing agency attendance and participation in IEP/transition planning meetings, and by using PATH plans to set and publicize team and local community goals.

- Teams that received TA were more likely to make progress on team development and collaborative interagency activities.

These findings support other interagency team literature (e.g., Canon-Bowers \& Bowers, 2011; Hu \& Liden, 2011; Hurlburt et al., 2014; Povenmire et al., 2015). Specifically:

- In order to evolve as teams, groups require at least 12 months of dedicated time to solidifying membership, determining community needs, setting elevating visions and goals, and pursuing non-threatening interagency activities.

- Groups require more than 12 months (more likely 24-36 months) to fully develop as teams before they are able to tackle collaborative interagency activities that require systemic changes such as fiscal and policy activities.

- Teams need systematic TA to address more advanced team development and collaborative interagency activities such as using data to set and measure goals, implementing strategies for building and sustaining local leaders, identifying strategies for assessing fiscal and policy needs, and developing MOAs and interagency agreements to address needs.

\section{Conflict of interest}

None to report.

\section{References}

Canon-Bowers, J. A. \& Bowers, C. (2011). Team development and functioning. In S. Zedeck (Ed.), APA handbook of industrial and organizational psychology: Vol.1 building and developing the organization (pp. 597-650). Washington, DC: American Psychological Association.

Everson, J. M., \& Guillory, J. D. (2002). Interagency teaming: Strategies for facilitating teams from forming to performing. New Orleans: Louisiana State University Health Sciences Center, Human Development Center.

Dedrick, R. F., \& Greenbaum, P. E. (2011). Multilevel confirmatory factor analysis of a scale measuring interagency collaboration of children's mental health agencies. Journal of Emotional Behavior Disorders, 19(1), 27-40.

Hu, J. \& Liden, R., (2011). Antecedents of team potency and team effectiveness: An examination of goal and process clarity and servant leadership. Journal of Applied Psychology, 96, 851862.

Hurlburt, M., Aarons, G.A., Fettes, D. Wilging, C., \& Gunderson, L. (2014, April). Interagency collaborative team model for capacity-building to scale-up evidence-based practice. Children and Youth Services Review, 39, 160-168.

Noonan, P. M., McCall, Z. A., Zheng, C., \& Erickson, A. S. (2012). An analysis of collaboration in a state-level interagency transition team. Career Development for Exceptional Individuals, 35, 143-154.

Povenmire-Kirk, T., Diegelmann, K., Crump, K., Schnorr, C., Test, D., Flowers, C., \& Aspel, N. (2015). Implementing CIRCLES: A new model for interagency collaboration in transition planning. Journal of Vocational Rehabilitation, 42, 51-56.

Repetto, J. B., Webb, K. W., Garvan, C. W., \& Washington, T. (2002). Connecting student outcomes with transition practices Florida. Career Development for Exceptional Individuals, 25, 123-139. 